\title{
PERCEPTIONS OF UNDERGRADUATE MEDICAL STUDENTS ABOUT PEER ASSISTED LEARNING.
}

1. MBBS, MPhil (Phys), MHPE Associate Professor Department of Physiology Peshawar Medical College

Peshawar

RIPHAH International University, Islamabad.

2. BDS, MPH, MHPE

Associate Professor

Institute of Health Professions

Education \& Research

Khyber Medical University,

Peshawar.

Correspondence Address Dr. Brekhna Jamil

Institute of Health Professions

Education \& Research

Khyber Medical University, Peshawar.

drbrekhna.iph@kmu.edu.pk

Article received on:

07/06/2018

Accepted for publication:

$12 / 04 / 2019$

Received after proof reading:

$31 / 07 / 2019$

\begin{abstract}
Robina Usman ${ }^{1}$, Brekhna Jamil ${ }^{2}$
ABSTRACT... To assess the perceptions of undergraduate medical students about peer assisted learning (PAL). Study Design: Cross sectional study. Setting: Peshawar Medical College. Period: From March 2016 to August 2016. Materials and Methods: A total of 84 students from second year MBBS were included to record the perceptions about peer assisted learning. A total of six topics of urogenital module were selected for PAL session. A validated questionnaire having 17 close ended questions was used to evaluate PAL on Likert-scale. The participants consented and evaluated the questionnaire, from which data was gathered and analyzed to reveal the degree of satisfaction by the PAL. Results: There were equal number of males and females (40 each). About $65-75 \%$ agreed that PAL was more informative than classical lecture system; topic discussed was clearer and found answers to their questions. $60-70 \%$ liked to incorporate peer assisted learning in their modules, showed satisfaction to the contents covered, felt easy to communicate with peer tutor and were of the view that peer tutors performed well in their teacher's role. Among peer tutors, $70-80 \%$ agreed that the endeavor improved their confidence in teaching, presentation and communication skills. Over $62 \%$ agreed that teaching at undergraduate level was a beneficial experience. Conclusion: The participants' found the peer assisted learning teaching method as useful. Therefore, this strategy may be introduced in the college.
\end{abstract}

Key words: $\quad$ Peer Assisted Learning, Peer Tutees, Peer Tutors, Teaching, Undergraduate.

Article Citation: Usman R, Jamil B. Perceptions of undergraduate medical students about peer assisted learning. Professional Med J 2019; 26(8):1283-1288.

DOI: 10.29309/TPMJ/2019.26.08.3870

\section{INTRODUCTION}

Peer learning is defined as "the acquisition of knowledge and skill through active helping and supporting among status equals or matched companions which involve people from similar social groupings who are not professional teachers, helping each other to learn and learning themselves by so doing." "It is the process of understanding, gaining skill or knowledge from students that are either at equivalent or different experiential or academic levels. ${ }^{2}$

PAL is an umbrella incorporating a variety of collaborative and cooperative educational strategies, including peer teaching, peer learning, peer assessment, peer mentoring, and peer leadership. ${ }^{2}$

The idea that knowledge is built via collective group dialogue is essential to the course of peers learning from one another. Vygotsky, in 1978 put forth the concept of a zone of proximal development and suggested that learning was facilitated by social interaction with more capable peers. $^{3}$

In the United Kingdom, the General Medical Council's Tomorrow's Doctors: Recommendations on Undergraduate Medical Education states that medical graduates must "function effectively as a mentor and teacher." ${ }^{4}$ Therefore, introduction of PAL program within an undergraduate curriculum could be helpful in preparing medical students for their future role as educators.

For the institution, PAL can reduce burden of teaching ${ }^{5}$ on faculty offering a measure for resource saving and accommodating the increasing number of medical students who begin their clinical activities early, in pre-clinical years. 5,6 
PAL can assist the institution to meet external expectations for medical graduates to achieve capability and experience in both teaching and assessment. ${ }^{6}$ PAL can also address specific gaps within the curriculum, ${ }^{7}$ providing additional student support in preparation for assessments. ${ }^{8}$

Multiple benefits of peer assisted learning have been highlighted in several studies such as confidence and motivation in the students, ${ }^{9}$ learning like clarifying the ambiguities, ${ }^{10}$ and had a progressive effect on students' reflective practice, improving their learning and integrating theory into practice. ${ }^{11}$

Peer assisted learning has been conducted in large group format in a study by Iram et al. ${ }^{12}$ Evidence of conducting PAL in small group format in undergraduate medical students was lacking. In this study a PAL session was conducted in small group format because of the multiple benefits to the students such as promotion of deep learning, discussion and communication skills, active and adult learning, self-motivation, development of transferrable skills, application and development of ideas. ${ }^{13,14}$

This study was conducted to assess the perceptions of students about PAL session in small group format at undergraduate level.

\section{METHODOLOGY}

This cross sectional study was carried out on $2^{\text {nd }}$ year MBBS students during August 2016 at Peshawar Medical College affiliated with Riphah University in Islamabad; Khyber Pakhtunkhwa. This is the only medical college who has adopted the integrated curriculum and has modular system. A total of 84 students consented to participate in this study. The four groups were made as per gender distribution and previous academic scores. Each group comprised of ten students, with equal number of male and female distribution. Literature strongly suggests that it will be good to have peer tutors from the same level with high academic score. ${ }^{15,16,17}$ Ten students (same level peer tutors) with academic scores greater than $75 \%$ were selected and they were not a part of any of the groups. Out of these ten students, four were selected by computer random method as peer tutors. The peer tutors attended the training workshop by expert facilitators who shared the knowledge about different methods of engaging students such as asking questions, referring to students by their names, listening to their answers attentively, maintaining eye contact with the students and providing feedback in a small group. A total of six topics of urogenital module were selected through consensus. The learning outcomes and material of the SGD topics were provided to peer tutors. After the sessions conducted by peer tutors, perceptions from all the participants were collected through a questionnaire comprised of 17 close ended questions, based on 5-point Likert scale. The questionnaire was validated through experts. All responses from participants were collected anonymously and analyzed by SPSS 19 .

\section{RESULTS}

Frequencies and percentages were calculated for each question. Mean scores were calculated for each question as highly satisfied (greater than 4), moderately (3-4) and not satisfied (less than 2.5). The details are shown in Table-I and II. The responses revealed that majority of the student tutees were in favor of PAL was a good teamwork experience, an interactive way of learning, stimulated motivation through comparison with fellow peers, is more informative than classical lecture system and the topic discussed got clearer.

A greater percentage was in favor that they found answers to their questions and would like to incorporate peer assisted learning in their modules. Furthermore, they were satisfied with the contents covered in PAL. They felt easy to communicate with peer as compared to facilitator and that in general peer tutor in their respective sessions performed well in their teacher roles i.e. peer tutor can be as effective as a teacher in small group settings. 


\begin{tabular}{|c|c|c|c|c|c|c|}
\hline No & Statement & $\begin{array}{c}\text { Strongly } \\
\text { Disagree } \\
1\end{array}$ & $\begin{array}{l}\text { Disagree } \\
\quad 2\end{array}$ & $\begin{array}{l}\text { Not Sure } \\
\quad 3\end{array}$ & $\begin{array}{l}\text { Agree } \\
\quad 4\end{array}$ & $\begin{array}{c}\text { Strongly } \\
\text { Agree } \\
5\end{array}$ \\
\hline A & \multicolumn{6}{|l|}{ As a Peer Tutee (In PAL) } \\
\hline 1 & I found it an interesting teamwork experience. & $\begin{array}{c}1 \\
(1.3 \%)\end{array}$ & $\begin{array}{c}5 \\
(6.3 \%)\end{array}$ & $\begin{array}{c}15 \\
(18.8 \%)\end{array}$ & $\begin{array}{c}30 \\
(37.5 \%)\end{array}$ & $\begin{array}{c}29 \\
(36.1 \%)\end{array}$ \\
\hline 2 & $\begin{array}{l}\text { I found it an interactive way of learning and } \\
\text { understanding. }\end{array}$ & 0 & $\begin{array}{c}2 \\
(2.5 \%)\end{array}$ & $\begin{array}{c}18 \\
(22.5 \%)\end{array}$ & $\begin{array}{c}30 \\
(37.5 \%)\end{array}$ & $\begin{array}{c}30 \\
(37.5 \%)\end{array}$ \\
\hline 3 & $\begin{array}{l}\text { It usually stimulates motivation through } \\
\text { comparison with fellow peers. }\end{array}$ & 0 & $\begin{array}{c}1 \\
(1.3 \%)\end{array}$ & $\begin{array}{c}17 \\
(21.2 \%)\end{array}$ & $\begin{array}{c}34 \\
(42.5 \%)\end{array}$ & $\begin{array}{c}28 \\
(35 \%)\end{array}$ \\
\hline 4 & $\begin{array}{l}\text { PAL is more informative than Classical lecture } \\
\text { system. }\end{array}$ & 0 & $\begin{array}{c}5 \\
(6.3 \%)\end{array}$ & $\begin{array}{c}21 \\
(26.2 \%)\end{array}$ & $\begin{array}{c}28 \\
(35 \%)\end{array}$ & $\begin{array}{c}26 \\
(32.5 \%)\end{array}$ \\
\hline 5 & I was clear about the topic we discussed. & $\begin{array}{c}2 \\
(2.5 \%)\end{array}$ & $\begin{array}{c}2 \\
(2.5 \%)\end{array}$ & $\begin{array}{c}22 \\
(27.5 \%)\end{array}$ & $\begin{array}{c}28 \\
(35 \%)\end{array}$ & $\begin{array}{c}26 \\
(32.5 \%)\end{array}$ \\
\hline 6 & I found answers to my questions. & 0 & $\begin{array}{c}4 \\
(5 \%)\end{array}$ & $\begin{array}{c}17 \\
(21.3 \%)\end{array}$ & $\begin{array}{c}32 \\
(40 \%)\end{array}$ & $\begin{array}{c}27 \\
(33.7 \%)\end{array}$ \\
\hline 7 & $\begin{array}{l}\text { I would like to incorporate peer assisted learning } \\
\text { in our modules. }\end{array}$ & $\begin{array}{c}1 \\
(1.3 \%)\end{array}$ & $\begin{array}{c}4 \\
(5 \%)\end{array}$ & $\begin{array}{c}20 \\
(25 \%)\end{array}$ & $\begin{array}{c}28 \\
(35 \%)\end{array}$ & $\begin{array}{c}27 \\
(33.7 \%)\end{array}$ \\
\hline 8 & I am satisfied with the contents covered in PAL. & 0 & $\begin{array}{c}3 \\
(3.8 \%)\end{array}$ & $\begin{array}{c}25 \\
(31.2 \%)\end{array}$ & $\begin{array}{c}24 \\
(30 \%)\end{array}$ & $\begin{array}{c}28 \\
(35 \%)\end{array}$ \\
\hline 9 & $\begin{array}{l}\text { I feel easy to communicate with peer as compared } \\
\text { to facilitator. }\end{array}$ & $\begin{array}{c}2 \\
(2.5 \%)\end{array}$ & 0 & $\begin{array}{c}10 \\
(2.5 \%)\end{array}$ & $\begin{array}{c}33 \\
(41.2 \%)\end{array}$ & $\begin{array}{c}35 \\
(43.8 \%)\end{array}$ \\
\hline 10 & $\begin{array}{l}\text { In general, peer tutor in their respective sessions } \\
\text { performed well in their teacher roles. }\end{array}$ & 0 & $\begin{array}{c}3 \\
(3.8 \%)\end{array}$ & $\begin{array}{c}25 \\
(31.2 \%)\end{array}$ & $\begin{array}{c}24 \\
(30 \%)\end{array}$ & $\begin{array}{c}28 \\
(35 \%)\end{array}$ \\
\hline 11 & $\begin{array}{l}\text { In general, I consider peer tutor can be as effective } \\
\text { as a teacher in small group settings. }\end{array}$ & $\begin{array}{c}1 \\
(1.2 \%)\end{array}$ & $\begin{array}{c}9 \\
(11.2 \%)\end{array}$ & $\begin{array}{c}13 \\
(16.2 \%)\end{array}$ & $\begin{array}{c}34 \\
(42.5 \%)\end{array}$ & $\begin{array}{c}23 \\
(28.7 \%)\end{array}$ \\
\hline B & \multicolumn{6}{|l|}{ As a Peer Tutor (PAL) } \\
\hline 1 & I believe this increased my confidence. & 0 & 0 & $\begin{array}{c}1 \\
(12.5 \%)\end{array}$ & $\begin{array}{c}3 \\
(37.5 \%)\end{array}$ & $\begin{array}{c}4 \\
(50 \%)\end{array}$ \\
\hline 2 & It increased my communication skills. & 0 & 0 & $\begin{array}{c}2 \\
(25 \%)\end{array}$ & $\begin{array}{c}2 \\
(25 \%)\end{array}$ & $\begin{array}{c}4 \\
(50 \%)\end{array}$ \\
\hline 3 & It increased my presentation skills. & 0 & $\begin{array}{c}1 \\
(12.5 \%)\end{array}$ & $\begin{array}{c}2 \\
(25 \%)\end{array}$ & $\begin{array}{c}4 \\
(50 \%)\end{array}$ & $\begin{array}{c}1 \\
(12.5 \%)\end{array}$ \\
\hline 4 & $\begin{array}{l}\text { It was a beneficial experience of teaching at } \\
\text { undergraduate level for me. }\end{array}$ & 0 & 0 & $\begin{array}{c}1 \\
(12.5 \%)\end{array}$ & $\begin{array}{c}4 \\
(50 \%)\end{array}$ & $\begin{array}{c}1 \\
(12.5 \%)\end{array}$ \\
\hline 5 & $\begin{array}{l}\text { I think the participants benefited from my } \\
\text { sessions. }\end{array}$ & 0 & 0 & $\begin{array}{c}2 \\
(25 \%)\end{array}$ & $\begin{array}{c}2 \\
(25 \%)\end{array}$ & $\begin{array}{c}4 \\
(50 \%)\end{array}$ \\
\hline 6 & $\begin{array}{l}\text { Every undergraduate student should learn to } \\
\text { teach. }\end{array}$ & 0 & 0 & $\begin{array}{c}1 \\
(12.5 \%)\end{array}$ & $\begin{array}{c}4 \\
(50 \%)\end{array}$ & $\begin{array}{c}3 \\
(37.5 \%)\end{array}$ \\
\hline
\end{tabular}

Table-I. Frequencies and percentages of students' responses to statements regarding perceptions of PAL

\section{DISCUSSION}

One of the outstanding ways of learning and teaching is teamwork where each participant is actively taking part in the learning process. It is noteworthy that relatively informal atmosphere stimulate more interaction between peers leading to more questions resulting in constructive discussion and ultimately more effective learning. ${ }^{18}$ Although learning from experts has been a tradition in medical teaching, there is a debate nowadays among educationalists whether experts are always the best people to teach. ${ }^{10}$ As experts may be unconscious of the learning stages that novices and intermediate learners go through, and thus they may be less suited to teaching junior students. ${ }^{19}$ Likewise, peers are deemed more approachable than faculty staff by the trainees. 


\begin{tabular}{|c|l|c|c|}
\hline No & \multicolumn{1}{|c|}{ Perceptions of PAL } & Mean \pm SD & Degree of Satisfaction \\
\hline 1 & Peer Tutees & & \\
\hline 2 & I found it an interesting teamwork experience. & $4.01 \pm .961$ & Highly satisfied \\
\hline 3 & It usually stimulates motivation through comparison with fellow peers. & $4.10 \pm .836$ & Highly satisfied \\
\hline 4 & PAL is more informative than Classical lecture system. & $3.94 \pm .919$ & Moderately satisfied \\
\hline 5 & I was clear about the topic we discussed & $3.93 \pm .965$ & Moderately satisfied \\
\hline 6 & I found answers for my Questions. & $4.03 \pm .871$ & Highly satisfied \\
\hline 7 & I would like to incorporate peer assisted learning in our modules. & $3.95 \pm .953$ & Moderately satisfied \\
\hline 8 & I am satisfied with the contents covered in PAL. & $3.96 \pm .903$ & Moderately satisfied \\
\hline 9 & I feel easy to communicate with peer as compared to facilitator. & $4.24 \pm .860$ & Highly satisfied \\
\hline 10 & $\begin{array}{l}\text { In general, peer tutor in their respective sessions performed well in } \\
\text { their teacher roles. }\end{array}$ & $3.96 \pm .906$ & Moderately satisfied \\
\hline 11 & $\begin{array}{l}\text { In general, I consider peer tutor can be as effective as a teacher in } \\
\text { small group settings. }\end{array}$ & $3.86 \pm 1.003$ & Moderately satisfied \\
\hline & Peer Tutors & & Highly satisfied \\
\hline 1 & I believe this increased my confidence & $4.38 \pm .744$ & Highly satisfied \\
\hline 2 & It increased my communication skills & $4.25 \pm .886$ & Hoderately satisfied \\
\hline 3 & It increased my presentation skills & $3.63 \pm .916$ & Highly satisfied \\
\hline 4 & $\begin{array}{l}\text { It was a beneficial experience of teaching at undergraduate level for } \\
\text { me }\end{array}$ & $4.25 \pm .707$ & Highly satisfied \\
\hline 5 & I think the participants benefited from my sessions. & $4.25 \pm .886$ & Highly satisfied \\
\hline 6 & Every undergraduate student should learn to teach. & $4.25 \pm .707$ & \\
\hline & & Table-II. Mean scores of perceptions of PAL & \\
\hline
\end{tabular}

By collecting data on perceptions of the PAL process, it was appreciated that the process results in enhancing presentation and communication skills of the tutees and tutors both.

In this study, both PAL and FAL have proved to be equally good teaching and learning strategies so PAL should supplement the available teaching strategy and some of the faculty members should oversee the PAL process in order to prevent students to get distracted.

Evidence of its application goes even beyond formal learning years as it plays an important role in continuous professional development of practicing physician. ${ }^{5}$

This study was carried out in small group discussions. Among peer students, 77\% agreed to the clarity of topic discussed. Mean score was 3.93 showing their moderate satisfaction. Similar results show in a study by Parr $^{20}$, that PAL supplement improved participants' understanding of topics through interactive small group activities.
Among peer students, $75.5 \%$ agreed that they would like to incorporate peer assisted learning in their modules with a mean score of 3.95. This shows a need of carrying out PAL in multiple modules for various purposes in order to make students more familiar with the process. In a study by Firdaus et al, ${ }^{21}$ the participants had also shows encouraging responses toward PAL and wanted to incorporate it in their future lessons.

In this study the students agreed that they were satisfied with the contents covered in PAL (mean score of 3.96). In the study carried out by Iram, $16(29.6 \%)$ students were satisfied with content coverage and $33(61.1 \%)$ were not satisfied. ${ }^{4}$ It has been documented that peer assisted learning has certain disadvantages. Sometimes the peer tutors are not well conversant with the topic and do not have full depth of knowledge; in that case, further confusions can be created for tutees. ${ }^{22}$ Our study showed moderate satisfaction with the contents coverage because the peer tutors were trained properly. 
In this study the peer students, agreed that they felt easy to communicate with peer as compared to facilitator showing a mean score of 4.24 . It has been proven by many studies that in comparison to teacher led lessons, peer assisted learning provides much safer environment for interactive learning. ${ }^{4}$

According to study by Menezes and Burgess et al, proximity in experience also creates a more comfortable, friendlier learning environment due to a reduced sense of authority. ${ }^{23}$ With peers as teachers, there can be a more effective and trusting dialogue established in the learning process, rather than a traditional teacher-student instructional relationship. Our data confirmed PAL to be a helpful aid to learning. ${ }^{14}$ However, in some cases of peer assisted learning, peer pressure, embarrassment and inappropriate behavior has also been reported. ${ }^{24}$

In this study the peer tutors strongly agreed that this strategy has increased their confidence. High satisfaction of the peer tutors is depicted by a mean score of 4.38. In a study by Asif Ali et al, peer tutors were found to have gained confidence in their teaching to a small group. As a peer tutor, all participants agreed that it caused an increase in confidence, improvement of communication and presentation skills. ${ }^{25}$ In another study by Burgess et al, the learning environment provided by the tutors promoted supportive interactions between the tutors and tutees that fostered confidence for both groups of students. ${ }^{26}$ The similar results showing high satisfaction rate is also shown in our study.

PAL is gaining an important status in medical education where the restricted resources have compelled teachers to introduce innovative educational environments which can be helpful in delivering education at a lower cost. ${ }^{6}$ Peer assisted learning is not only effective but well enough to address curricular outcomes as well. ${ }^{27}$ To implement PAL in Pakistani medical institutions is the need of the day due to broadening of curriculum and comparative lack of teaching staff. Faculty should be trained to become familiar with PAL and should change stance towards the continuously changing trends of medical education and help in incorporating new teaching methodologies. Such studies should be repeated at different medical colleges on a larger scale before making PAL as a part of curriculum.

\section{CONCLUSION}

PAL supplements the available teaching strategy which will not only lessen the burden on faculty but it will make students responsible for their own learning. PAL should be included in the curriculum on regular basis and incorporated in different modules.

Copyright (C) 12 Apr, 2019.

\section{REFERENCES}

1. Topping KJ. The effectiveness of peer tutoring in further and higher education: A typology and review of the literature. High Educ. Springer; 1996; 32(3):32145.

2. Henning JM, Weidner TG, Marty MC. Peer assisted learning in clinical education: Literature review. Athl Train Educ J. National Athletic Trainers' Association; 2008; 3(3):84-90.

3. Brown AL, Ferrara RA. Diagnosing zones of proximal development. LEV Vygotsky Crit Assess. 1999; 225-53.

4. Council GM, Kingdon U. Tomorrow's doctors. Recommendations on undergraduate medical education. 1993.

5. Romito A. Peer assisted learning. Essent Handb GP Train Educ ed Mehay R, Ed Available online essentialgptrainingbook com. 2014;

6. Yu T-C, Wilson NC, Singh PP, Lemanu DP, Hawken SJ, Hill AG. Medical students-as-teachers: a systematic review of peer-assisted teaching during medical school. Adv Med Educ Pract. Dove Press; 2011; 2:157.

7. Perkins GD, Hulme J, Bion JF. Peer-led resuscitation training for healthcare students: A randomized controlled study. Intensive Care Med. Springer; 2002; 28(6):698-700.

8. Hurley KF, Mckay DW, Scott TM, James BM. The supplemental instruction project: Peer-devised and delivered tutorials. Med Teach. Taylor \& Francis; 2003; 25(4):404-7.

9. Kibble JD. A peer-led supplemental tutorial project for medical physiology: Implementation in a large class. Adv Physiol Educ. Am Physiological Soc; 2009; 33(2):111-4. 
10. Khaw C, Tonkin A, Kildea H, Linn A. Peer observer feedback sheets: A tool for structured peer feedback. Focus on Health Professional Education: A Multi-disciplinary Journal. 2011 Mar;12(3):41.

11. Ladyshewsky RK, Gardner P. Peer assisted learning and blogging: $A$ strategy to promote reflective practice during clinical fieldwork. Australas $\mathrm{J}$ Educ Technol. 2008; 24(3):241-57.

12. Manzoor I. Peer assisted versus expert assisted learning: A comparison of effectiveness in terms of academic scores. J Coll Physicians Surg Pakistan. $2014 ; 24(11): 825-9$.

13. Kitchen M. Facilitating small groups: How to encourage student learning. Clin Teach. 2012; 9(1):38.

14. Steinert Y. Student perceptions of effective small group teaching. Med Educ. Wiley Online Library; 2004; 38(3):286-93.

15. Knobe $M$, Münker $R$, Sellei RM, Holschen M, Mooij SC, Schmidt $\square$ Rohlfing $B$, et al. Peer teaching: A randomized controlled trial using student $\square$ teachers to teach musculoskeletal ultrasound. Med Educ. Wiley Online Library; 2010; 44(2):148-55.

16. Sarwar S, Tarique S. Peer-Assisted Learning: Who Should Be the Tutor, Fellow Student or Senior Resident? J Coll Physicians Surg JCPSP. 2016; 26(7):573.

17. Burgess A, McGregor D, Mellis C. Medical students as peer tutors: A systematic review. BMC Med Educ. BioMed Central Ltd; 2014; 14(1):115.

18. Hayashi S, Tsunekawa $\mathrm{K}$, Inoue $\mathrm{C}$, Fukuzawa $\mathrm{Y}$. Comparison of tutored group with tutorless group in problem-based mixed learning sessions: A randomized cross-matched study. BMC Med Educ. BioMed Central Ltd; 2013; 13(1):158.
19. Longfellow E, May S, Burke L, Marks-Maran D. "They had a way of helping that actually helped": A case study of a peer-assisted learning scheme. Teach High Educ. Taylor \& Francis; 2008; 13(1):93- 105.

20. Field M, Burke JM, McAllister D, Lloyd DM. Peerassisted learning: A novel approach to clinical skills learning for medical students. Med Educ. Wiley Online Library; 2007; 41(4):411-8.

21. Jahan F. Siddiqui MA, Al Maashari B, Al Lawatia F. Students' Perception regarding Peer Assisted Teaching and Learning in Family Medicine Rotation at Oman Medical College. Diversity and Equality in Health and Care (2016) 13(2): 210-14.

22. Kitchen $M$. Facilitating small groups: How to encourage student learning. Clin Teach. 2012; 9(1):38.

23. Maheady L. Advantages and Disadvantages of PeerAssisted. Peer-assisted learning. 1998:45.

24. Glynn LG, MacFarlane A, Kelly M, Cantillon P, Murphy AW. Helping each other to learn-a process evaluation of peer assisted learning. BMC Med Educ. BioMed Central Ltd; 2006; 6(1):18.

25. Ali A, Evans P. Multi-Resource peer assisted learning in postgraduate setting: A pilot study. J Coll Physicians Surg Pakistan. 2013; 23(4):251-6.

26. Burgess A, Dornan T, Clarke AJ, Menezes A, Mellis C. Peer tutoring in a medical school: Perceptions of tutors and tutees. BMC Med Educ. BioMed Central; 2016; 16(1):1.

27. Bennett D, O'Flynn S, Kelly M. Peer assisted learning in the clinical setting: an activity systems analysis. Adv Heal Sci Educ. Springer; 2015; 20(3):595-610.

\begin{tabular}{|c|c|c|c|}
\hline \multicolumn{3}{|c}{ AUTHORSHIP AND CONTRIBUTION DECLARATION } \\
\hline Sr. \# & Author-s Full Name & \multicolumn{1}{c|}{ Contribution to the paper } & Author=s Signature \\
\hline 1 & Robina Usman & $\begin{array}{l}\text { RU designed study collected } \\
\text { and analyzed the data. Edited } \\
\text { all drafts of paper. } \\
\text { BJ helped in generation of } \\
\text { idea, Edited all drafts of paper. }\end{array}$ \\
\hline 2 & Brekhna Jamil &
\end{tabular}

